Salesian Journal of Humanities and Social Sciences, Vol. X, No. 2 (Dec 2019)

ISSN: 0976-1861 | 10.51818/SJHSS.10.2019.48-70 | Page: 48-70,

Section: Articles

\title{
Gandhi's Legacy: Vandana Shiva as Gandhi's Heir
}

Pius V Thomas is Faculty at the Department of Philosophy, Assam University, Silchar. Areas of specialization are Contemporary Western Philosophy, Critical Hermeneutics, Ethics-Applied Ethics, Theories of Democracy, Religion and Human Rights, Philosophies of Mahatma Gandhi and Rabindranath Tagore. His current research interests are focused on the question of the possibility of contextualizing Human Rights, along with cultural critique, which stimulates themes like Philosophical concepts of Interculturality and Critique, Ethics and Reason, Democracy and Religion, Environmental Ethics and the Philosophy of Education. He has a good number of papers and articles to his credit.

Violina Patowary is M Phil candidate at the Department of Philosophy, Assam University, Silchar. She has published a good number of papers in reputed.

The paper highlights the contemporariness and legacy of Gandhian thought in its influence on the concepts of democracy, ethics of plurality and political morality. The paper, however, routes its discussion about democracy to show how it assumes the status of a radical critique of globalized world, global institutions, the environment and nature. The discussion that is carried out in the paper tries to see how a very radical and intimate interlocutor of our time like Vandana Shiva builds up her ecofeminist theoretical environmentalism and the principles of global coexistence and democracy through a paradigm that can be called Gandhian. The paper further argues to show up that the concept of earth democracy, which Vandana Shiva puts forward to mediate a major environmental ethical and socio-political ideal in addressing what we call broadly the environmental crisis, as it articulates an important ecosophical framework, precipitates the Gandhian ideal of Swaraj. The paper, therefore, tries to draw attention to the delicate conceptual positions that Vandana Shiva establishes in her main arguments in linking the global environmental thought or ecological philosophy with the principles of earth democracy and the unique principle of biospherical equality to make them stand in intimate dialogue with the world of Gandhian ideas.

Key words: Political Gandhi, Swaraj, Earth Democracy, Ecological Democracy, Earth Citizenship. 
Gandhi's Legacy: Vandana Shiva as Gandhi's Heir / 49

Salesian Journal of Humanities and Social Sciences, Vol. X, No. 2 (Dec 2019)

ISSN: 0976-1861 | 10.51818/SJHSS.10.2019.48-70 | Page: 48-70,

Section: Articles

\section{Introduction: Situating Gandhi}

In one of the current articles which discuss a well-known Malayalam Poet's understanding of Gandhi, the author wrote that the Poet was following a political Gandhi and not Gandhi as a symbol or image. What the author meant was that very many discourses on Gandhi resort to Gandhi as symbol or image, created out of a culturally and socially hybrid discourse. ${ }^{1}$ Ram Puniyani reflects the same when he observed recently as he was commenting on the view of a section of people, writers and intellectuals who are labelling Gandhi as racist and casteist, the one who harmed the cause of Dalits in India, in connection with the 'Black Lives Matter' agitation worldwide. Puniyani writes, "Nothing can be farther from truth. These elements are not seeing the whole journey of the man but do the cherry picking from his early writings, when he was in the early phases of his work against prevalent injustices in the name of race and caste." 2 Puniyani continues to write:

Mahatma Gandhi, the Father of Indian Nation, has the unique distinction of leading the biggest ever mass movement in the World and leading the strong anti-colonial movement. In this direction he contributed two major tools as the basis of the mass movements, the one of non-violence and other of Satyagraha. He also stated that while making the policies what one should keep in mind is the last, weakest person in the society. His life, which he called as his message became the inspiration of many anti-colonial, anti-racial struggles in different parts of the World. He strongly supported the concept of equality in India, where eradication of caste also became one of the aims of his life. ${ }^{3}$

As Gandhi himself appeared to have said - warning those who want to follow his ideas - that he might have modified his views

1 Gopikrishmnan P N, Mahakaviyum Mahatmavum (Poet and the Mahatma), Mathrubhoomi Weekly, June, 30, 2019,12-19.

${ }^{2}$ Ram Puniyani, 'Gandhi Race and Caste', http//www.group.google.com/msgid/secular perspective.

${ }^{3}$ Ibid. 


\section{0 / Pius V Thomas \& Violina Patowary}

Salesian Journal of Humanities and Social Sciences, Vol. X, No. 2 (Dec 2019) ISSN: 0976-1861 | 10.51818/SJHSS.10.2019.48-70 | Page: 48-70,

Section: Articles

according to the latest understanding and therefore stick to the last view in this regard. Gandhi here was gently admitting his fallibility and the possible self-contradiction in him. As Gandhi writes:

The opinions I have formed the conclusions that I have arrived at are not final. I may change tomorrow; I have nothing new to teach the world. Truth and nonviolence are as old as the hills. All I have done is to try experiments in both on as vast scale as I could do. In doing so, I have sometimes erred and learnt by my errors. Life and its problems have thus become to me so many experiments in the practice of truth and nonviolence. ${ }^{1}$

As Ananda Kumarasamy beautifully observes, "He was constantly on the lookout for any traces of deception within him, so that he could root them out. He strived to become authentic, which is the ability to be oneself in front of others. Gandhi did not wear any masks - he always displayed his real self. He was not afraid of letting others know who he really was." ${ }^{2}$ What we see here can be called the virtue of democratic challenge to conceptual deification and political infallibility. The paper proposes to affirm here that the authenticity in Gandhi blends with the the virtue of democratic challenge to conceptual and ideological deification and political infallibility' to shape and ground the 'political Gandhi'. Gandhi becomes undoubtedly a contemporary political, social and cultural icon, world over.

Therefore, the legacy of Gandhian thought as its influence on contemporary philosophy and social theory is-simultaneously-chastising and obscurantist. Nonetheless, Gandhi and his philosophy prominently figures in all discussions about democracy, ethics of plurality and political morality.

\section{The Core of Gandhi's Thought}

Deeper than the iconic ideals celebrated after Gandhi, such as, Nonviolence as Personal Ethics, Religion as Truth and Morality, it is more important

\footnotetext{
${ }^{1}$ Gandhi M K., Harijan, March 28, 1936.

${ }^{2}$ Anand Kumarasamy, Gandhi On Personal Leadership, (New Delhi: Jaico Books, 2005), 163.
} 
according to the latest understanding and therefore stick to the last view in this regard. Gandhi here was gently admitting his fallibility and the possible self-contradiction in him. As Gandhi writes:

The opinions I have formed the conclusions that I have arrived at are not final. I may change tomorrow; I have nothing new to teach the world. Truth and nonviolence are as old as the hills. All I have done is to try experiments in both on as vast scale as I could do. In doing so, I have sometimes erred and learnt by my errors. Life and its problems have thus become to me so many experiments in the practice of truth and nonviolence. ${ }^{4}$

As Ananda Kumarasamy beautifully observes, "He was constantly on the lookout for any traces of deception within him, so that he could root them out. He strived to become authentic, which is the ability to be oneself in front of others. Gandhi did not wear any masks - he always displayed his real self. He was not afraid of letting others know who he really was." 5 What we see here can be called the virtue of democratic challenge to conceptual deification and political infallibility. The paper proposes to affirm here that the authenticity in Gandhi blends with the the virtue of democratic challenge to conceptual and ideological deification and political infallibility' to shape and ground the 'political Gandhi'. Gandhi becomes undoubtedly a contemporary political, social and cultural icon, world over.

Therefore, the legacy of Gandhian thought as its influence on contemporary philosophy and social theory is-simultaneously-chastising and obscurantist. Nonetheless, Gandhi and his philosophy prominently figures in all discussions about democracy, ethics of plurality and political morality.

\section{The Core of Gandhi's Thought}

Deeper than the iconic ideals celebrated after Gandhi, such as, Nonviolence as Personal Ethics, Religion as Truth and Morality, it is more important

\footnotetext{
${ }^{4}$ Gandhi M K., Harijan, March 28, 1936.

${ }^{5}$ Anand Kumarasamy, Gandhi On Personal Leadership, (New Delhi: Jaico Books, 2005), 163.
} 


\section{2 / Pius V Thomas \& Violina Patowary}

Salesian Journal of Humanities and Social Sciences, Vol. X, No. 2 (Dec 2019)

ISSN: 0976-1861 | 10.51818/SJHSS.10.2019.48-70 | Page: 48-70,

Section: Articles

to see how Gandhi diagnostically views and challenges the perverted combination of colonialism and the uncritical modernity as the one dimensional technological domination of the natural and the cultural domains as the real violence. Ahimsa/Nonviolence is in recognizing them as they are and critiquing them. As pointed out by Ramin Jahanbegloo:

In response to the totalizing project of modernity exemplified by colonial domination and a discursive dominance of positivist and reductionist science, Gandhi laid down two conditions for the enshrinement of moral civilization in Hind Swaraj. First, his notion of Swaraj, which referred to three philosophical, ethical and political ideas of self examination, self rule and self determination. Second, his concept of Sarvodaya or welfare of all, which rejected the Utilitarian view of liberal democracy as representing greatest good of the greatest number. ${ }^{6}$

Consequently, Gandhi shows us the violence involved in the deadly combination of techno-scientific capitalism and it's ideal of domination of nature, brute force and economic greed.

A K Saran sums up Gandhi's ideals of Swaraj, Sarvodaya and Satyagraha (Socio-economic and political philosophy) in tandem with the root ideal that is Ahimsa:

1. Means and ends should be seen as parts of $s$ whole which has transcendental reference. 2. The production system should be based on the ideal of progressive and regulated minimization of needs (and not on that of multiplication of wants). 3. The economy should be life centered and not one that is commodity centered. It should be based on a nonexploitative economy based on simple and limited technology. 4. Social and economic organization should be based on decentralized, based on the principle of optimum autonomy. 5. Truth and Ahimsa should be the foundation of the political order. 6. Satyagraha (the determined pursuit of truth) should be chief form of political vigilance and protest. 7 . The social and the economic systems should be hierarchical, non competitive, and non acquisitive, based on the principle of trusteeship (Social trusteeship-

\footnotetext{
${ }^{6}$ Ramin Jahanbegloo, The Decline of Civilization, (New Delhi: Aleph Books, 2017), 44-45.
} 
People's rights). Ideally it should be a stateless society. ${ }^{7}$

However, Gandhian concept of democracy which presumes nonviolence as its guiding principle has been intensely criticized by many thinkers like Ambedkar, Marxists, recently very prominently, Arundhati Roy as well as the recent critics of institutionalized democracy. They criticize Gandhi's concept of democracy and non-violence finally stands for the social violence (Himsa) like caste/Dalit freedom issue, the lose areas of the idealized uncertainty of minorities' and political plurality's issue and the loosely understood question of language-identity.

The present paper as it gives due credit to the limitations of Gandhian thought, presumes that the precincts that the political Gandhi draws and the debate such conceptual determinants summon, opens an epochal grounding for Gandhian thought(s). In other words, as very well debated figure of the contemporary thinking, let us assume that there are many tenors in locating and triggering off the contemporariness of Gandhian thought and also many ways of approaching his thought and its significance. The present paper, in such an attempt, draws attention to how Vandana Shiva, one of the most discussed present day ecophilosopherecofeminist and ecological activists, situates Gandhi and his philosophy in formulating and articulating her theory of earth democracy.

\section{Vandana Shiva's Gandhi}

Vandana Shiva is a world-renowned environmental thinker and campaigner. A former physicist, feminists and philosopher, a leader and innovator in development theory, she is prominent in citizen's actions against environmental destruction, and critical of the latest agricultural and genetic engineering technologies and the giant corporations which control them. ${ }^{8}$ Shiva plays a prominent role in International Forum on

${ }^{7}$ Saran A K, "Gandhi's Theory of Society and Our Times", In Fred Dallmayr and Devy(ed) Between Tradition and Modernity, (New Delhi: Sage,1998), 210.

${ }^{8}$ Vandana Shiva, a well-known environmentalist and an Ecofeminist, was born on 5th November, 1952 in Dehra Dun, Uttaranchal. As born and brought up in Dehra Dun, which is near the foothills of the Himalayas, she has developed an interest in environmentalism. 


\section{4 / Pius V Thomas E Violina Patowary}

Salesian Journal of Humanities and Social Sciences, Vol. X, No. 2 (Dec 2019)

ISSN: 0976-1861 | 10.51818/SJHSS.10.2019.48-70 | Page: 48-70,

Section: Articles

\section{Globalisation which creates constructive response towards various issue}

Her father was a forestry official and a farmer, from whom she was able to know about both the positive outcome and the negativity that surrounds in the farming profession. After completion of her master degree in the Philosophy of Science, and also having her doctorate degree in "Hidden Variables and Non-locality in Quantum Theory" from the department of Philosophy at the University of Western Ontario in 1978, she returned home with a view to work for the environmental related issues and save earth from illness. She preceded her work from grass-root movements and campaigns to prevent construction of clear cut loggings, deforestation, over uses of pesticides and chemical fertilizers in farming etc. She was the Indian environmentalist, whose name is related to the Chipko Movement, which literally means the tree-hugging movement. She is best known as a critic of Asia's Green Revolution. Green revolution was an international attempt to increase food production through high yielding food, organisms stock which further needs high level of chemical fertilisers, preservatives etc. These high yielding seeds, foods again destroy the local and indigenous varieties of seeds and also give troubles in the poor farmers. As a response to this, she with the help of her foundation named Research Foundation for Science and Technology and Ecology (RFSTE), established by her in 1982, RFSTE scientists established seed banks throughout India to preserve agricultural heritage and train farmers about sustainable farming techniques.

Along with Ralph Nader and Jeremy Rifkin, Vandana Shiva won the Alternative Nobel Peace Prize (the Right Livelihood Award) in 1993. This is an annual award given to individuals for "outstanding vision and work on behalf of our work on planet and people" (The Right Livelihood Award, 20 Oct. 2008). This award was conferred upon Shiva for her leadership in ".....placing women and ecology at the heart of modern development discourse" (The Right Livelihood Award, V. Shiva. 20 Oct. 2008).In India she is Director of the Research Foundation of Science, Technology and Ecology, which led to the creation of Navdanya: network of seed keepers and organic producers spread across 17 states in India. She is also the founder of BijaVidyapeeth which offers conference and seminar facilities in an ambiance which reinvigorates our vital link with Nature at the Navdanya Biodiversity Conservation and Agro Ecology Farm in the foothills of the Himalayas. Now to the primary question, what is Navadanya; its stated mission is to "protect nature's and people's rights to knowledge, biodiversity, water and food" (NavdanyaSeed Sovereignty 15 Jan 2009).A multidimensional work is to be done by it. But its primary focus is to seed saving and chemical free agriculture. Apart from this organic farming, sustainable forest and agriculture, biodiversity conservation, food security of people etc. are come under the province of it. Again in the broader sense it too tries to focus on to see women and nature; and men and women equally and supports grassroots women movements. Finally, Navdanyamotivates education and research regarding various practices in agriculture. It tries to teach farmers about uses to organic agricultural mechanism for disease free environment and health hazards, and teaches about the harmful effects of chemical uses and biodiversity's impact on farming.

Vandana Shiva has written many books and articles related to environmental protections. Her major works includes: Staying Alive: Women, Ecology and Development (1990), The Violence of the Green Revolution: Third World Agriculture, Ecology and Politics (1991), Ecology and Politics of Survival: Conflicts over Natural Resources in India (1991), Ecology and Politics 
related to globalisation. She discusses how globalisation affects the poorest countries, farmers and people living in rural area. It is like capitalism i.e. rich becomes richer and poor becomes poorer. She scrutinizes that the progressive ideals of free trade and globalization actually inhabit growth for the poorest in the world, while encouraging excess wealth to the rich capitalist.

Inspired by women's struggles for the protection of nature as a condition for human survival Shiva shows how ecological destruction and the marginalization of women are linked. They are not inevitable, economically or scientifically. She argues that "maldevelopment" or the violation and exploitation of natural processes into corporate interest make the nature too mechanical, which in turn to destroy not only the human survival on earth, but also will destroy the whole earth one day. Every area of human activity now-a-days downgrades and burdens both nature and women. There is only one path, according to Shiva, to survival and liberation of women (and men) and nature. And that is the ecological path of harmony, sustainability and diversity. She explores the unique place of women in the environment of India in particular, both as its saviours and as victims of maldevelopment.

For Shiva destruction of biodiversity and marginalization of women go hand in hand. Therefore, women have to come forward to control both.

of Survival: Conflicts over Natural Resources in India (1991), Biodiversity: Social and Ecological Perspectives (1992), Women, Ecology and Health: Rebuilding Connections (1993), Close to Home: Women Reconnect Ecology, Health and Development (1994), Stolen Harvest: The Hijacking of the Global Food Supply (2000), Tomorrows Biodiversity: Prospects for Tomorrow (2000), Water Wars: Privatisation and Profit (2000), Protect or Plunder: Understanding Intellectual Property Rights (2001), Plants, Myths and Reality (2001), India Divided (2005), Globalisation's New Wars: Seeds, Water and Life Forms (2005), Manifestos on the Future of Food and Seed (2007), Democratising Biology: Reinventing Biology from a Feminists, Ecological and Third World Perspective (2007), Cargill and Corporate Hijack of India's Food and Agriculture (2007), Soil not Oil: Environmental Justice in a Time of Climate Crisis (2008), Monoculture of the Mind: Perspectives on Biodiversity (2011), Earth Democracy: Justice, Sustainability and Peace (2011), Biopiracy: The Plunder of Nature and Knowledge (2011), Making Peace with the Earth (2013), The Vandana Shiva Reader (2015), Seed Sovereignty, Food Security: Women in the Vanguard (2016), Who Really Feeds the World: The Failures of Agribusiness and the Promise of Agroecology (2016), Another important book she written with Maria Miles is Ecofeminism (1993), Biopolitics with Ingunn Moser (1995), Apart from this she has written many articles, papers etc. 


\section{6 / Pius V Thomas E Violina Patowary}

Salesian Journal of Humanities and Social Sciences, Vol. X, No. 2 (Dec 2019)

ISSN: 0976-1861 | 10.51818/SJHSS.10.2019.48-70 | Page: 48-70,

Section: Articles

In this era of monocultural capitalism, the soil suffers a lot. It can't help but bear the illness. In the same way the (women) farmers also suffers. Women are often most directly involved person with subsistence work, and are safeguards of natural resources needed to sustain both her family as well as the community sector. Shiva argues that "women's work and knowledge is central to biodiversity conservation and utilisation both because they work between 'sectors' and because they perform multiple tasks," ${ }^{\prime \prime}$ It is said that to develop a society it is necessary to develop it from the root. So Shiva tries to organise the house worker women to come forward for dual liberation of women as well as nature. Shiva summed the situation by saying, "liberation is best to begin from the colonised and end with the coloniser." 10

By mentioning the irony of the Third World women, Shiva says many of the problems faced by the third world women today are the historical result of colonial relations between the first and the third worlds. In her work Staying Alive: Women, Ecology and Development, Shiva offers a paradigmatic analysis of the dilemma of third world women everywhere. The erosion of traditional land-use rights by the introduction of cash cropping strips these women from having control over their means of production. For centuries women engaged hands-on with habitat to provide food and shelter. But technologically transferred development ruptures this re/productive nature women- labour nexus, leaving starvation and ecological destruction in its place. In the same way Green Revolution of agriculture (seeds, fertilizers, pesticides, dams, irrigation equipment and tractors), plantation forestry (fast-growing, non-indigenous species, herbicides, chip harvesters, and mills), capitalist ranching (land conversion, imported grasses, fertilizers and factory farms) and reproductive technologies (potentially harmful contraceptive drugs, sterilization, and bottle feeding) have further disrupted native ecologies and people. As subsistence farmers, urban workers and middle class professionals, their ability to provide basic subsistence and healthy living condition is threatened; therefore the third world women have

\footnotetext{
${ }^{9}$ Miles, and Shiva, Ecofeminism, (New Delhi: Zed Books, 2004), 166.

${ }^{10} \mathrm{Ibid}, 165$.
} 
born to challenge of eco degradation and ecologically unsustainable developments projects as well as their human rights. They have organized movements to transform maldevelopment into sustainable development. Chipko is one such example of movements later organized by Shiva to protect tree for felling and balance ecology.

Regarding forestry Shiva says that forest has two paradigms: positive and negative. Positively it is life-enhancing and negatively it is lifedestroying. The life-enhancing paradigm emerges from the forest itself and the feminine principle; and life-destroying from the factory and the market. Since the maximising of profits is consequent upon the destruction of conditions of renewability, the two paradigms are cognitively and ecologically can never be judged with same standard. Life-enhancing factor has emerged from India's ancient forest culture, in all its diversity, and has been renewed in contemporary times by Chipko effort. Shiva was a participant in the Chipko movement in 1970 (and onwards).Food security and seed freedom is another area where Shiva's philosophy of life moves around. She rejects the corporate patents on seeds, by calling it 'Biopiracy'. As Schell contends:

She has campaign against the implementation of the WTO 1994 Trade related Intellectual Property Rights (TRIPS) agreement which broadens the scope of parents to include life forms. Shiva has criticised the agreement as having closed ties with the business sector and opening the door to further patents on life. Shiva fought against attempted patents of several indigenous plants, such as Basmati, Neem etc. ${ }^{11}$

From the aforementioned points we can sum up her philosophy. Her philosophy is to democratize the whole earth. If we go for the roots we can find that she grounds her work on Gandhian philosophy. She tries to challenge today's problems of the whole world by following Gandhi's mantra 'be the change you want to see in the world'. 


\section{8 / Pius V Thomas E Violina Patowary}

Salesian Journal of Humanities and Social Sciences, Vol. X, No. 2 (Dec 2019)

ISSN: 0976-1861 | 10.51818/SJHSS.10.2019.48-70 | Page: 48-70,

Section: Articles

\section{Gandhi's Philosophy: Vandana Shiva's Affinities}

According to Vandana Shiva, Gandhi's philosophy is a living philosophy. It gives hope, freedom, and way of life in the negative situations. Shiva admits that the impact of Gandhi in her life, towards way of democratisation of earth helps a lot. His creative vision of Swadeshi (self-reliance); Swaraj (self-rule); Satyagraha (struggle for truth) and Sorvodaya (upliftment of all) inspires Shiva in her creative vision of earth democracy. By wishing good of ours satyagraha and localising good and services i.e. (swadeshi) we can have self-rule (swaraj) and avoid corporate rule on us, so that our people can have uplift (sarvodaya) without any corporation. Relating to the three amendments of our patent act, Shiva remembers Gandhi's work, "as long as the superstition that people should obey unjust laws exists, so long will slavery exist."12 So to avoid such laws, Navdanya comes forward to protect against all these unjust laws towards our nature.

In one of her interview with Scott London, Shiva expresses that, "Gandhi is the only person who knew about real democracy - not democracy as the right to go and buy what you want but democracy as the responsibility to be accountable to everyone around you. Democracy begins with freedom from hunger, freedom from unemployment, freedom from fear, and freedom from hatred. To me, those are the real freedoms on the basis of which good human societies are based." ${ }^{13}$ To respond various environmental issues Navdanya (nine seeds) movement was started by Vandana Shiva in the year 1984 which tries to give support and direction towards various kinds of environmental activism. To minimise or to end environmental negative conditions Navdanya does many works. Branching off from Gandhi's thought she advocate her own strong philosophy i.e. Earth democracy which based on the thinking 'VasudhaivaKutumvakam' which means the whole earth is one family. Shiva calls it the "community of all beings supported by the earth." 14 In

${ }^{12}$ V. Shiva, “The practice of Earth Democracy: Looking Ahead- Experiences from 30 years of Participatory Research and Community Action", Development Dialogue, 52(2009): 94.

13 "In the Footprints of Gandhi: An Interview with V. Shiva", Scott London, February 3, 2016. www.globalresearch.ca

${ }^{14}$ Shiva, V, Earth Democracy: Justice, Sustainability and Peace, (New Delhi: Natraj Publishers, 
earth democracy, Shiva explains, "the concern for human and non-human species comes together in a coherent, non-conflicting whole that provides an alternative to the world view of corporate globalisation, which gives right only to corporations and which sees humans and other beings as exploitable raw material or disposable waste." ${ }^{15}$ Earth democracy is that which includes peace, justice, sustainability with total rejection of violence. Things that belong to nature, we cannot have the right to buy or sell it. We can just use it in sustainable way.

\section{Earth Democracy: From Suicidal Economy to Life Saving Economy}

Due to corporations like Monsanto, Cargill the monocropping seeds enters into the firms of the poor peasants which needs many chemical based fertilizers and pesticides and cannot be saved for further, replacing their save seeds. Farmers are seduced with false promise of becoming rich and forced every year to buy these engineered seeds. As a result they fall in indebtness and poverty which further leads to the selling of their kidneys and ultimately to suicide of the peasants as Shiva points. "The privatisation of public goods and services and the commodization of the life support systems of the poor is a double theft which robs people of both economic and cultural security."16 These imply that the survivals of the small farmers are incompatible with profit-motivated-globalcorporations. Another problem is the trade related laws which allows these corporations to ruin our farmers as well as biodiversity. So the reason for failure of dominant economic model can be seen in two ways:

Reduction of the visible economy to only market economy and all the related activities are controlled by corporate ignoring the nature's economy and sustenance economy where actually all of them depend.

The legal rights of corporations have increased at the cost of real people and natural heritage.

2011), 1 .

${ }^{15}$ Ibid, 8.

${ }^{16}$ Ibid, 3. 


\section{0 / Pius V Thomas \& Violina Patowary}

Salesian Journal of Humanities and Social Sciences, Vol. X, No. 2 (Dec 2019) ISSN: 0976-1861 | 10.51818/SJHSS.10.2019.48-70 | Page: 48-70,

Section: Articles

Earth Democracy is in short a response towards all these profit oriented destructive motives. Earth democracy movement demonstrate a new society which will return 'everything to everyone', which actually their own and can be realised through "can begin with constructive action and turn it into our best resistance." ${ }^{17}$ What Eco-socialist tries for is justice for all people and protest against mono-crop and mono-thought. The earth democracy movement shows us way how we can get our nature back from destructive foundation. By intuiting and upholding democratically established laws against dominant models and also government who allows such things to us and through overturning "superstition that people should obey unjust laws." 18 However Shiva's concept of Earth Democracy is not a concept born out of nothing. Broadly speaking, we can relate it to many theories like Marxian, Gandhian etc. She is inspired by many. But Gandhi's concepts are seen as most relatable to her many concepts which together give birth to Earth Democracy.

\section{Sovereignty to End Slavery: Navdanya's Outlook}

To respond the various negative issues related to the environment and illness of the earth Navdanya started a new paradigm to respond to these problems. It helps us to shift from dominant and pervasive culture to a peaceful culture with non-violent ways. This response is broadly termed as 'earth democracy' by Vandana Shiva: "It is not just about the next protest or the next World Social Forum; it is about what we do in between. It addresses the global in our everyday lives, our everyday realities, and creates change globally by making change locally." ${ }^{19}$ Here humans are embedded in earth family where every human beings and nonhuman organisms have collectivity in various forms such as ecological, economical - and whereby - greed and consumerism are replaced by sustainable livelihood. Shiva highlights the sovereignty movement by

\footnotetext{
${ }^{17}$ Shiva, V. “The practice of Earth Democracy: Looking Ahead- Experiences from 30 years of Participatory Research and Community Action", Development Dialogue, 52(2009): 94.

${ }^{18}$ Ibid, 94.

${ }^{19}$ Shiva, V, Earth Democracy: Justice, Sustainability and Peace, (New Delhi: Natraj Publishers, 2011), 4.
} 
pronouncing that, "Our world is not for sale, our water is not for sale, our seeds and biodiversity are not for sale." ${ }^{20}$

\section{Seed and Food Sovereignty}

"Seed is not just the source of life. It is the very foundation of our being." 21 Following Gandhi's concept of non-violence and salt satyagraha, earth democracy also launched seed sovereignty against various seed related issues like genetic engineering, seed laws and patents laws which make farmers slave of their own farming due to corporate ruling - as the farmers have to pay royalties to the companies for using hybrid seeds. Farmers only work as means to gain profit for the large companies like Monsanto, Syngenta, and Cargill. "The seed, for the farmer, is not merely the source of future plants and food; it is the storage place of culture and history. Seed is the first link in the food chain. Seed is the ultimate symbol of food security." 22 Seed sovereignty movement demands that Indian laws do not legalise patents on seeds and food, and Trade Related Intellectual Property Rights (TRIPs) is reviewed to exclude patents on seed and food. "The system of seeds based on monoculture is wrong and inappropriate. The bio diverse system has produced more food, and biodiversity means that seeds must be in the hands of farmers." ${ }^{23}$ Bija Swaraj extends its hands to save seeds from other problematic issues like protect seeds from virus and other infection attack, campaign for localising the seed markets. Genetically modified seeds have many negative effects, so it tries to ban it and to save biodiversity by saving the earth from transgenic seeds and its all harmful effects on soil, ecology and human health and exploitation of farmers. Because of these genetic pollution and other normal problems related to pollution, healthy and organic food processing also is in danger and difficulty. The other reason of these toxic spreading is that they

\footnotetext{
${ }^{20}$ Ibid, 2.

${ }^{21}$ Shiva, V, The Vandana Shiva Reader, (Kentuky: University Press of Kentuky, 2014), 35.

${ }^{22}$ Shiva, V. Stolen Harvest: The Hijacking of the Global Food Supply, (Boston: South End Press, 2000), 8 .

${ }_{23}$ "Vandana Shiva: Seeds must be in the Hands of Farmers", interview with Mark Trans, February 25, 2013. www.theguardian.com
} 


\section{2 / Pius V Thomas \& Violina Patowary}

Salesian Journal of Humanities and Social Sciences, Vol. X, No. 2 (Dec 2019) ISSN: 0976-1861 | 10.51818/SJHSS.10.2019.48-70 | Page: 48-70,

Section: Articles

are cheap. But if we account for the true costs of these chemical based seeds and food, we realise that they are unaffordable; because nothing can be achieved at the cost of the environment. So the seed satyagraha says public money that is used in biotechnology's high projects like GMO, it should be used in organic farming and nourishment. "In every application of genetic engineering, food is being stolen from other species for the maximisation of corporate profits." ${ }^{24}$

Denying people the right to healthy life and poison-free food by enacting anti-people laws and policies; using public money in non-sustainable farming is termed as 'food-dictatorship'. Navdanya has established 54 seeds banks in 16 different states and it has climatic resilient properties which helps local farmers and it also established a conservation and training centre to train farmers about organic and local farming.

For the democratic and decentralised food system, Navdanya launched its campaign on food rights and food sovereignty (Anna Swaraj) at the Anna Panchayat (Public Tribunal on Hunger) in May 2001. ${ }^{25}$ Organic foods have many health benefits too. But global food markets use various preservative to preserve food for longer. Preservative has many side effects on health. Again entry of large companies like Cargill into direct procurements, processing, transportation it directly affects the small local food industry and its employees. Food is our fundamental human rights, so we have the right to good and beneficial food. Large sale business related to food at the cost of local food market and health should not be allowed.

\section{Water Sovereignty}

Navdanya also work for the Jal Swaraj i.e. Water Sovereignty. "Water must be free for sustenance needs. Since nature gives water to us free of cost buying and selling it for profit violates our inherent right to nature's gift and

\footnotetext{
${ }^{24}$ Shiva, V, Stolen Harvest: The Hijacking of the Global Food Supply, (Boston: South End Press, 2000), 16.

${ }^{25}$ navdanya.org/earth-democracy.
} 
denies the poor of their human rights" 26 . So, in 2000, Navdanya launched the water sovereignty movement to protect our water from privatisation, commodification and to promote traditional water harvesting system and establish excess to water. Water is the most commercial product now-adays. Since growing population demands more fresh water and industrial works, agricultural sector also needs water, so there becomes scarcity of water, which motivated commercial workers to commercialise the water. In some rural areas women have to walk $2 / 3$ kilometres to get water. Draught is another reason to water scarcity. As a protest, World Bank scheme of privatising Delhi's water supply to Svez are stopped by RFSTE and Citizen Font of Water Democracy; Coca-Cola's thievery of Kerala's ground water; river linking projects like Ken Betwa and Sharda-Yamuna of Bundelkhand and Uttrakhand accordingly, which are nothing but theft of our water and water heritage.

\section{Land Sovereignty}

For the development of any country proper land use is important. Land is basically used for agriculture and food production. So, sustainable land use is very much important. Vandana Shiva stood against land ceiling, sale of agricultural land for non-agricultural purpose, multinational company's grabbing of land from small farmers and Dalit's to earn tax benefits in the name of exports etc. The big multinational companies like Monsanto, Cargill that attracts marginal farmers into monocropping and hybrid seeds that in turn ruin soil fertility and damage the land, driving the farmers deeper into debt and finally leading to suicide. These also gives birth other related issues like increased unemployment, migration, hunger problem, malnutrition, disease and death. So to protect land and community rights, economic and food security in broader sense are dealt with by Bhu Swaraj. Land must belong to those who nurture it, not for those who use it unsustainably.

Shiva's Earth Democracy is the response towards all these sufferings of nature. To respond these it has some principles of its own. Vandana Shiva

${ }^{26}$ Shiva, V, Water Wars: Privatisation and Profit, (Boston: South End Press, 2000), 35. 


\section{4 / Pius V Thomas E Violina Patowary}

Salesian Journal of Humanities and Social Sciences, Vol. X, No. 2 (Dec 2019)

ISSN: 0976-1861 | 10.51818/SJHSS.10.2019.48-70 | Page: 48-70,

Section: Articles

in her book Earth Democracy: Justice, Sustainability and Peace mention about ten principles of Earth Democracy. They are outlined in the next point.

\section{Principle of Earth Democracy}

Vandana Shiva's earth democracy has 10 major principles, i.e. with these 10 principles we can better understand what exactly earth democracy is according to Shiva. They are briefly outlined below:

Ecological Democracy- Democracy of all life:

This implies all the species of the earth including human and non-human organisms have equal right over the earth. Though human beings are the highest kind of animal yet it does not mean that she/he has the sole right on earth and treat others cruelly and with violence. Everything has the right of same ecological space.

Intrinsic Worth of all Species and People:

All organisms: human and non-humans have intrinsic worth of their own. Nothing can be used as one's own need and object of manipulation. No human have a right to destroy or own nature's species at the cost of so called patents or intellectual property rights. All are free - all have worth.

Diversity in Nature and Culture:

Earth is full of biological as well as cultural diversity. We should defend all as it is our duty. Considering it as separate, having value and richness of its own we should respect both nature and culture equally. Nothing is higher than that of the other.

Natural Rights to Sustenance:

Earth is a world family having its diversified species. All have some birth-rights on nature like right to live, right to food and water, security on ecological space, habitat, and usage of natural resources in short, towards healthy sustenance. These are the rights as we get as an earth 
citizen. Nobody has the right to snatch them. These rights are not given by corporate or state, so nor can they be deprived by them. They have no right to privatization or monopoly control of our nature and natural rights.

Earth Economy is based on Economic Democracy and Living Economy:

Economic democracy is the basis of earth democracy. Economic system deals with overall livelihood of people, including basic needs, removal of worldwide hunger problem, economic sustainability etc. Protection of the integrity of the natural ecosystem also comes under the ambit of ecodemocracy. Earth's economy is a living economy which includes various areas of healthy living i.e. sustainability, diversity, pluralistic system that protect peoples, natures and work for the overall benefits of the world.

Living Economies are based on Local Economies:

Our earth is blessed with many resources for the smooth running of the people's life. But they are not extremely available - as they are handy for needy not for greedy. So for the better uses of resources, conservation of earth's resources and creation of sustainable and satisfying livelihood is most caringly, creatively, efficiently and equitably achieved at the local level. Localisation of economies is a social and ecological necessity for the preservation of nature. Think globally act locally should be the motto of people. Only those goods which cannot be produced locally due to climate and other reasons are to be imported or produced non-locally. Earth democracy is based on vibrant, resilient local economies, and rich tribal foods. We should respect them and should not allow global economy to destroy local economy.

\section{Living Democracy:}

Earth democracy is based on local living democracy. It includes all the local communities, their similarities, diversities, their involvement towards local ecology, rights, concept of sustainable development and right decision making towards the nature and natural resources; and livelihoods of all sorts of people. Authority is no doubt given on 


\section{6 / Pius V Thomas E Violina Patowary}

Salesian Journal of Humanities and Social Sciences, Vol. X, No. 2 (Dec 2019)

ISSN: 0976-1861 | 10.51818/SJHSS.10.2019.48-70 | Page: 48-70,

Section: Articles

government but it should be based on the principle of subsidiarity. Earth democracy is living democracy.

\section{Living Knowledge:}

Living knowledge implies up-to-date knowledge system according to ages, differences subsides in the world. It maintains and reviews living processes and contributes towards the stability and the goodness of the planet. Earth democracy is based on this community centred and earth centred knowledge which is further based on life centeredness and embedded in nature and society. It is not abstract or reductionist - rather - it allows all communities to create various such types of knowledge and keep it alive. It is knowledge of the earth, not of corporations. They have no right to change or have authority over this knowledge.

Balancing Rights with Responsibilities:

In earth democracy rights are derived from and balanced with responsibilities. One who can take the consequences of good or bad kind of result, of any actions is to be allowed for taking or making decisions. So called rich or authoritative people or many corporate sector are not allowed to take decision for the natural issues and common people's life. Responsibility in the sense of life giving, nature protection, sustainability in all sector are on the shoulders on the decision maker in any nature related issues.

Globalising Peace, Care and Compassion:

Earth democracy wants to connect peoples of various tribes, communities with the circle of care, cooperation and compassion. It does not agree with so called conflict and competition among communities. Conflict should be replaced with peace and greed with compassion globally, earth democracy pronounces.

After the discussion of these ten principles of Earth Democracy it is necessary to deal with Shiva's school of Bija Vidyapeetha, where she and her co-environmentalist teach about how to treat nature and our fellow 
human beings, what is the duty of every rational beings towards their surroundings, how to react and give response towards the reconstruction of the nature or environment that has already damaged.

\section{BijaVidyapeetha for Earth Citizenship}

Vandana Shiva with her co-environmentalists established BijaVidyapeetha - the school for seeds in 2002 at Navdanya firm. BijaVidyapeetha teaches us the human values of love and reverence for all life and personal involvement in nature and natural work to sustain it. Self-participation to stand against natural dilemma, various human problems can cure earth from illness. Ignorance or escaping from these also is a crime - a crime not to protect nature. It is the education of our earth identity i.e. our commonality with other humans and natural things. We human beings are not the highest of all - rather we are the members of the earth family, where everything has equal value. All have different appearance, aims, habits, works but all are same in the sense that all shares their livelihood on earth. So it's not conflict but cooperation should be the guiding principle of human nature.

Shiva says that embodied learning is unable to teach us real values, motives of our lives. But learning from nature and biodiversity helps us to understand and teaches us value of life i.e. connection, generosity, partnership, sharing, openness, celebration, protection, cooperation etc. which are essential for our survival. By mentioning about John Locke's view of mind as a 'tabula rasa' i.e. empty, Shiva says that we have to fill this emptiness with right kind of education. Learning for ecological consciousness and earth-citizenship is the main motto of Bija Vidyapeetha. Like Bija Vidyapeetha, there is a movement called Living Democracy Movement, related to the rethinking about environmental degradation and searching for the solutions of such problems. As a part of the broad vision of Earth Democracy movement it is also a movement against TRIPs and GMO. 


\section{8 / Pius V Thomas \& Violina Patowary}

Salesian Journal of Humanities and Social Sciences, Vol. X, No. 2 (Dec 2019)

ISSN: 0976-1861 | 10.51818/SJHSS.10.2019.48-70 | Page: 48-70,

Section: Articles

\section{Living Democracy Movement}

Living Democracy Movement otherwise known as Jaiva Panchayat is the movement against exploitation. Taking Gandhi's words as inspiration, "[i]t is necessary for us to emphasise the fact that no one need to wait for anyone else in order to adopt a right course. People generally hesitate to make a beginning, if they feel that the objective cannot be had in its entirety. Such an attitude of mind is in reality a bar to progress" 27; living democracy says that we can begin our protest when we feel necessity. Following the principles of earth democracy, protection of all life and nature on earth is the main objective of this movement. "The declaration of Jaiva Panchayat was made by 200 villages in June 2000. Since then the movement has spread to more than 6000 villages. It has been a major instrument for defending the seed and biodiversity sovereignty of the communities." 28 They aim at not to allow any illegal means to enter into natural resources to exploit it, and they associate themselves in conservation, sustenance and just use of natural resources. They deal with all the matters that are related to biodiversity. Through a decentralised democratic decision only one can realise the true democracy for life. Not only plants and seeds, they try to protect animal exploitation and conserve medicinal plants.

Living democracy movement was a series of actions taken against WTO and its TRIPs agreement. Through Intellectual Property Rights corporations pirated everything. They give notice to then director general of WTO to see the matter. They continue their movement against GMO also and stood against non-cooperation in biopiracy and destruction of mother earth. Jaiv Panchayat also forwards their hands to stop water privatisation in Orissa and Uttrakhand. Jaiv Panchayat tries to symbiosis local-global in positive sense. Starting from local level protest against TRIPs and GMO and saying people about its negativity, now it becomes global protest. Ecological farming method and indigenous crops are far better than that of modified crops. This living democracy can continue

${ }^{27}$ M.K. Gandhi, “Equal Distribution”, Harijan, 15 August, 1940.

28 V. Shiva, Earth Democracy: Justice, Sustainability and Peace, (Uttarakhand: Natraj Publishers, 2011), 97. 
till all the people realise nature, we-human, non-humans organisms are nothing but the members of the earth family and we all should think good of all irrespective of greed, conflict, war.

\section{Conclusion}

David Cortright ${ }^{29}$ in one of his books on Gandhi's philosophy and its influence on the world discussed different classical and contemporary examples of Gandhian thinking which have been contextualized world over. Gandhi's influence in the USA, Cortright calls that a cross fertilized tool for social justice, which was made use of for the struggle for peace. He presents Martin Luther King Jr. as an American who re-Christianized Gandhi in order to achieve a 'Realist Pacifism'. Cortright further takes us to the applied Gandhism in reinventing the boycott as a powerful instrument in the field, how the Gandhian faith became a 'mission of love', and'peace devotion' in thinkers and activists like Dorothy Day and Barbara Deming, who invents the power of revolutionary non-violence. We also cannot forget the celebrated Gandhains like Nelson Mandela, Robert Hart and Bernard Lefayetta and scores of others whose list may run into hundreds of names.

As we have discussed, when we come to Vandana Shiva's concept of earth democracy we can see that it is an organic elaboration and deepening of Gandhi's ideal of Swaraj. In order to aim to achieve earth democracy as decentred democracy and coexistence, Vandana Shiva grounds the ideal of Swaraj into the sovereignty of the world of the ordinary men and women, which challenges the state of ecological slavery. It ultimately affects our day to day lives to economic lives and eventually the whole of existence.

Vandana Shiva's ecological democracy as earth democracy endorses a grass-root level model of Gandhi's 'Swaraj, Sarvodaya and Satyagraha'. The concepts such as earth economy based on economic democracy and living economy engenders local economies supported by food security. As we have seen earth economy based on economic democracy is managed ${ }^{29}$ David Cortright, Gandhi and Beyond, (New Delhi: Viva Books, 2007). 


\section{0 / Pius V Thomas \& Violina Patowary}

Salesian Journal of Humanities and Social Sciences, Vol. X, No. 2 (Dec 2019) ISSN: 0976-1861 | 10.51818/SJHSS.10.2019.48-70 | Page: 48-70,

Section: Articles

by an enlightened and liberated notion of gender equality. It leads to living democracy enriched with living knowledge which balances rights with responsibilities and with an idea of earth citizenship. Earth citizenship as a category of earth democracy supports and sustains a more spontaneous and just principle of coexistence. 